\title{
Tolerance Induction by Viral In Vivo Gene Transfer
}

\author{
Eric Dobrzynski, PhD and Roland W. Herzog, PhD
}

\begin{abstract}
Treatment of genetic disease by protein or gene replacement therapy is hampered by immune responses to the therapeutic protein. An excellent example is formation of inhibitory antibodies to coagulation factors in treatment of the $\mathrm{X}$-linked bleeding disorder hemophilia. Experiments in murine and canine models of hemophilia $B$ (deficiency in factor IX) have demonstrated sustained therapeutic levels of factor IX transgene expression following hepatic adeno-associated viral gene transfer in animals with deletion and nonsense mutations in the factor IX gene. This article reviews experimental evidence for induction of immune tolerance to the factor IX transgene product by hepatic adeno-associated viral gene transfer, which has been shown to limit $T$ helper cell responses and to substantially reduce the risk of antibody responses. Tolerance induction is associated with activation of regulatory $\mathrm{CD} 4^{+} \mathrm{T}$ cells capable of suppressing antibody formation to factor IX protein. Hepatic administration of adeno-associated viral vector expressing ovalbumin in mice transgenic for a $\mathrm{T}$ cell receptor specific for this antigen provided direct evidence for induction of $\mathrm{CD}^{+} \mathrm{T}$ cell tolerance, including $\mathrm{T}$ cell anergy and clonal deletion. Taken together, these data indicate the potential for viral in vivo gene transfer not only to provide sustained systemic expression, but moreover to induce immunological hypo-responsiveness to the therapeutic gene product.
\end{abstract}

Keywords: Adeno-associated virus; Factor IX; Gene therapy; Hemophilia; T cell; Tolerance

\begin{abstract}
A
major concern in treatment of inherited protein deficiency by protein or gene replacement therapy is the risk for an immune response to the therapeutic protein which, by definition, differs from the mutation-carrying variant expressed by the recipient of therapy. For example, hemophilia is an X-linked bleeding disorder caused by mutations in the coagulation factor VIII (hemophilia A) or factor IX (hemophilia B) gene.
\end{abstract}

The most serious complication of current therapy (i.e., intravenous infusion of protein concentrate) is the potential for the formation of inhibitory antibodies to the intravenously infused clotting factor protein, which occurs at a frequency of $25 \%-30 \%$ in hemophilia A and $3 \%-4 \%$ in hemophilia B. ${ }^{1}$ Immune tolerance protocols for elimination of inhibitors in patients include frequent high-dose infusion of factor concentrate along with immunoglobulin and/or immunosuppressive drugs. ${ }^{2}$ Data from several Phase I clinical trials in gene therapy using different vectors and target organs have not found any inhibitor formation in patients. ${ }^{3,4}$ Even though no inhibitors have been observed in these clinical

Reprint Requests: Roland W. Herzog, PhD, University of Florida, Progress Park, 13706 Innovation Drive, Room 20I, Alachua, FL 326I5-9586, Tel: 386-462-6I39, Fax: 386-462-4099, E-mail: rherzog@ufl.edu trials, it should be noted that these patients were carefully selected based on previous history of inhibitor development during protein replacement therapy. In the case of muscle-directed factor IX gene transfer, only patients with missense mutations in the factor IX gene were enrolled in the trial. $^{5}$

Inhibitor formation has been observed following gene therapy in pre-clinical animal studies in hemophilic mice or dogs. ${ }^{6}$ The risk of inhibitor formation in these animals is influenced by multiple factors, including the type and design of the gene transfer vector, route of administration, vector dose, transgene expression levels and the underlying native gene mutation. Another important difference between the preclinical animal studies and the human trials is that gene transfer was performed in naïve animals, while the human subjects may have developed immune tolerance due to repeated intravenous infusion of factor concentrates. Thus the prediction of inhibitor formation following the animal studies may be of particular relevance if gene transfer protocols were performed in previously untreated patients. 


\section{Immune Responses to Coagulation Factors - General Considerations}

Inhibitor formation against factor VIII or factor IX is dependent on $\mathrm{CD}^{+} \mathrm{T}$ helper cells. The $\mathrm{T}$ cell receptor of $\mathrm{CD}^{+} \mathrm{T}$ cells binds to a specific peptide antigen-major histocompatibility complex (MHC) class II complex expressed on the surface of antigen presenting cells (e.g., dendritic cells or macrophages). This process may lead to $\mathrm{T}$ cell activation, which through similar interaction between the activated $\mathrm{T}$ and $\mathrm{B}$ cells can lead to $\mathrm{B}$ cell activation and subsequent antibody formation. Signaling to the $\mathrm{T}$ cell through the $\mathrm{T}$ cell receptor is referred to as signal 1 . In addition to $\mathrm{T}$ cell receptor signaling, activation of a naïve $\mathrm{T}$ cell requires co-stimulatory signals from the antigen presenting cells, also termed signal 2. If the $\mathrm{T}$ cell does not receive adequate stimulatory signals from the antigen presenting cells, tolerance may be induced. ${ }^{7}$ Expression of co-stimulatory molecules on the surface of antigen presenting cells is dependent on their activation status. Endogenous (e.g., cytokines) as well as exogenous (e.g., molecular structures associated with pathogens) activation signals have been described. ${ }^{7}$

Upon activation, $\mathrm{CD}^{+} \mathrm{T}$ cells differentiate into $\mathrm{T}$ helper cells. The type of $\mathrm{T}$ helper cell that is being activated depends, among other factors, on the cytokine milieu present during the interaction between the $\mathrm{T}$ cell and the antigen presenting cells. Subsets of $\mathrm{T}$ helper cells can be differentiated by their cytokine expression pattern and include Th1, Th2 and Th3 cells. Typically, Th1 cells produce interferon (IFN)- $\gamma$, tumor necrosis factor (TNF)- $\alpha$ and interleukin (IL)-2; Th2 cells produce IL-4, IL-5, IL-10 and transforming growth factor (TGF)- $\beta$; and Th 3 cells produce high amounts of TGF- $\beta$. Type $1 \mathrm{~T}$ regulatory $(\mathrm{Tr} 1)$ cells produce large amounts of IL-10 and are immune suppressive. Th1, Th2 and Th3 cells are all capable of activating B cells and promoting antibody formation, however, the particular subclass of immunoglobulin produced differs. Th1 cells promote IgG2a formation in mice (equivalent to IgG1 in humans), Th2 cells cause IgG1 formation in mice (IgG4 in humans) and Th3 cells drive IgA formation (typically secreted to mucosal surfaces). Inhibitory antibodies are typically comprised of IgG1 and/or IgG2a in mouse models and IgG1 and/or IgG4 in humans. Additionally, Th1 cells provide help for $\mathrm{CD} 8^{+} \mathrm{T}$ cells which, in contrast to $\mathrm{CD}^{+} \mathrm{T}$ cells, are MHC class I restricted and differentiate into cytotoxic $\mathrm{T}$ lymphocytes upon activation. This is more of a concern in gene-based treatment, because activation of cytotoxic $\mathrm{T}$ lymphocytes could lead to destruction of cells expressing the therapeutic protein. ${ }^{8}$

\section{Gene Protocols May Differ in Their Risk for Immune Responses}

There are a variety of vectors capable of transferring a functional coagulation factor gene. The choice and design of the vector can have a profound effect on the likelihood and specifics of an immune response. For example, the capsid of adenoviral vectors elicits a potent innate immune response which causes vector dose-limiting toxicity. ${ }^{9}$ Adenoviral and lentiviral vectors (if pseudotyped with envelope from vesicular stomatitis virus-G) efficiently transduce professional antigen presenting cells, thereby increasing the risk of cellular and antibody-mediated immune responses to the transgene product. ${ }^{10,11}$

While all gene therapy protocols and vector systems, not unlike conventional protein-based therapy, bear some risk of inhibitor formation, several lines of research have established that this risk can be reduced by restricting transgene expression to hepatocytes and/or by limiting the interaction of the vector with antigen presenting cells. ${ }^{10,12-17}$ Incorporation of a tightly regulated hepatocyte-specific promoter has been shown to limit antibody formation to secreted transgene products in the context of adenoviral or lentiviral vectors. ${ }^{10,12}$

Studies from two laboratories on retrovirus-mediated gene transfer to livers of neonatal mice and dogs with hemophilia A or B resulted in sustained curative levels of factor VIII and factor IX. ${ }^{18-20}$ Further analysis with a human factor IX transgene showed that this approach can lead to induction of robust immune tolerance to the therapeutic gene product. ${ }^{21}$ This work takes advantage of differences in the immune system of neonatal compared to older animals, which provides a window of time when the immune system is not fully matured and immune tolerance induction is facilitated.

Our approach toward treatment of hemophilia B is based on in vivo gene transfer with adeno-associated viral vectors. These are derived from a single-stranded, naturally replication-deficient and non-pathogenic member of the parvovirus family with a $4.7 \mathrm{~kb}$ single-stranded DNA genome. ${ }^{22}$ The vector contains a factor IX expression cassette, but is devoid of viral coding sequences. Adeno-associated viral vectors can efficiently transfer genes to non-dividing target cells such as muscle fibers and hepatocytes. Intramuscular, as well as hepatic administration, has led to sustained systemic factor IX expression and partial correction of hemophilia B in small and large animal models. ${ }^{14,23-30}$ Both strategies were subsequently tested in Phase I/II clinical trials. $5,31,32$ Hepatic gene transfer was typically carried out by injection of vector into the portal vein or the hepatic artery. A comparison of both protocols in several animal models of hemophilia B indicated a reduced risk of inhibitor formation by the hepatic route. $6,13,14,30$ Sustained factor IX expression was observed even in animals with a factor IX gene deletion or nonsense mutation. ${ }^{14,27,28}$ Once the adeno-associated viral (serotype 2) vector is infused into the liver, a tropism toward hepatocytes ultimately results in factor IX expression in approximately $5 \%$ of hepatocytes, with vector dose-dependent levels of expression. ${ }^{29,33}$ We now asked the question of whether this observed sustained expression in the absence of inhibitor formation is linked to induction of immune tolerance to the transgene product. 

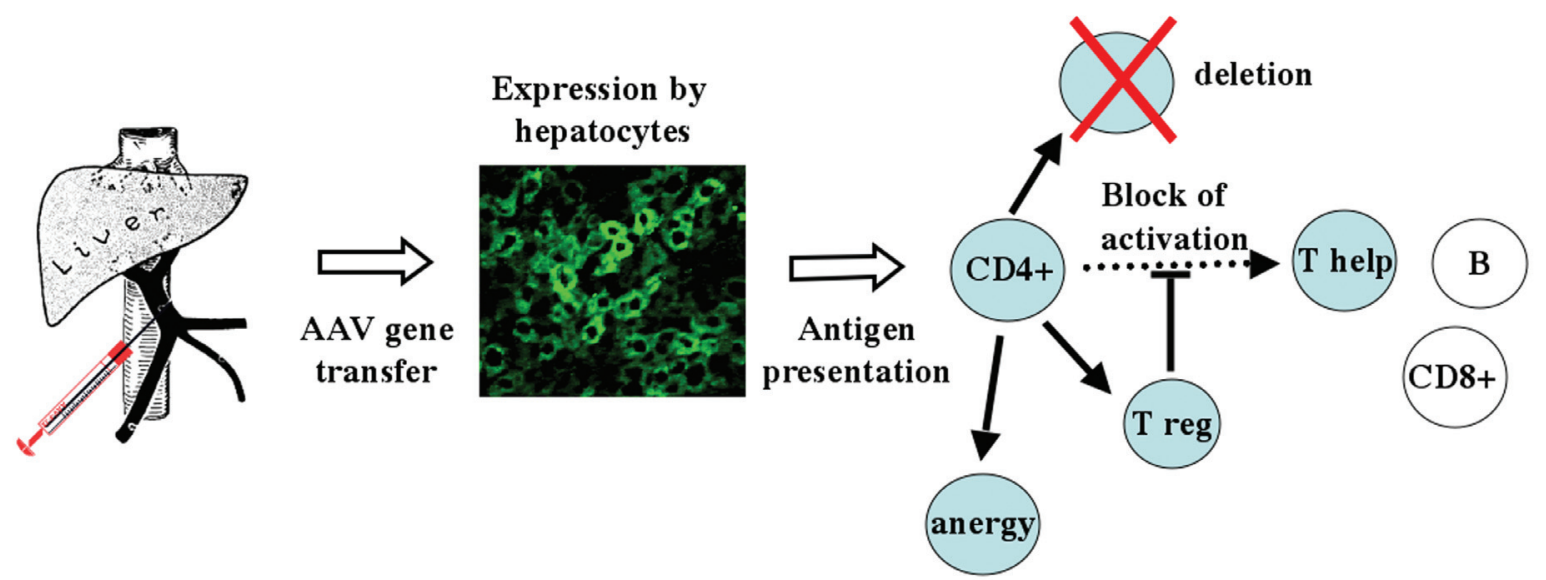

Immune tolerance

Figure 1. Model for induction of immune tolerance to a therapeutic gene product by hepatic adeno-associated viral-mediated gene transfer. Vector is infused into the hepatic circulation resulting in gene transfer and transgene expression in hepatocytes (green stain). Subsequent presentation of transgene product-derived peptides via MHC class II molecules (likely through professional antigen presenting cells) to naïve $\mathrm{CD}^{+}{ }^{+} \mathrm{T}$ cells causes induction of $\mathrm{T}$ cell anergy and deletion of transgene product-specific $\mathrm{T}$ cells or causes activation of regulatory $\mathrm{T}$ cells. The latter suppress activation of any remaining responsive CD4+ $\mathrm{T}^{+}$cells. As a consequence of these mechanisms, there is a lack of $T$ helper cell responses, in turn causing failure to activate B cells and CD8+ T cells. Ultimately, antibody or cytotoxic $T$ cell responses are not observed or are limited.

Tolerance Induction to Factor IX by Hepatic Adeno-Associated Viral Gene Transfer

The ability to induce tolerance to a therapeutic protein in an adult animal by in vivo gene transfer would provide new perspectives and possibilities to the field of gene replacement therapy. Our initial experimental system to address these questions was hepatic gene transfer of a human factor IX cDNA by adeno-associated viral administration to immune competent adult mice of different strain backgrounds. ${ }^{15}$ From studies with other routes of administration, it was clear that human factor IX represented a neo-antigen to which these animals were not tolerant. One could now test whether immunological unresponsiveness to human factor IX after hepatic adeno-associated viral gene transfer was due to tolerance or ignorance. To this end, mice were challenged by subcutaneous administration of human factor IX in complete Freund's adjuvant several weeks after gene transfer. Control mice did not receive gene transfer or were injected with an adeno-associated viral vector expressing an irrelevant gene product (green fluorescent protein). While controls formed antibodies to human factor IX, hepatic adeno-associated viral-human factor IX transduced mice failed to respond to the immunization. ${ }^{15}$

Additional studies demonstrated antigen-specific tolerance induction and suggested that a level of expression of approximately $30 \mathrm{ng} / \mathrm{ml}$ plasma was required for tolerance induction. Some strains of mice showed an antibody response to human factor IX after low dose vector administration, but were tolerized at higher vector doses or if a stronger promoter was chosen. A detailed dose escalation revealed that levels of transgene expression as determined by the combination of vector dose, promoter strength and mouse strain determined whether immune tolerance was achieved.15 Induction of immune tolerance was also documented in hemophilia B mice with a factor IX gene deletion, albeit with a lower success rate, suggesting that endogenous factor IX expression may facilitate tolerance induction. Furthermore, data in this experimental system revealed a correlation between lack of B cell and lack of $\mathrm{T}$ helper cell responses affecting Th1 and Th2-dependent responses. ${ }^{15,34}$

In general, mechanisms leading to $\mathrm{T}$ cell unresponsiveness include $\mathrm{T}$ cell anergy (a state of unresponsiveness associated with lack of IL-2 cytokine expression), clonal deletion of antigen-specific $\mathrm{T}$ cells or activation of regulatory $\mathrm{T}$ cells (Treg). Whether a $\mathrm{T}$ cell is tolerized or activated to become an effector cell depends on the activation status of the antigen presenting cells that interact with $\mathrm{T}$ cells. Activation of antigen presenting cells is dependent on "danger" or inflammatory signals. Thus, the context of antigen presentation (e.g., type of tissue, inflammatory signals provided by gene transfer vector or injury) plays a significant role in $\mathrm{T}$ cell activation. Depending on the target tissue, local cytokine concentrations may also skew T cell activation. For example, it is known that antigen presentation in lymphoid tissues associated with mucosal surfaces can induce Treg, meaning that $\mathrm{CD}^{+} \mathrm{T}$ cells activated in this context differentiate into $\mathrm{T}$ helper cells that suppress immune responses through secretion of certain cytokines such as IL-10 or TGF- $\beta$ (more information can be found in literature on oral and nasal tolerance). Examples for such induced Treg include Trl and Th3 cells with immune suppressive properties. On the other hand, there are also "naturally occurring" regulatory T cells that are generated through stimulation with self-antigens. These $\mathrm{CD}^{+} \mathrm{CD} 25^{+} \mathrm{T}$ cells constitutively express the $\alpha$ chain of the IL-2 receptor (CD25) and are critical for prevention of autoimmune disease. ${ }^{35}$ If gene transfer resulted 
in activation or generation of $\mathrm{CD} 4{ }^{+} \mathrm{CD} 25^{+}$Treg, this could be significant for maintaining tolerance.

In our hepatic adeno-associated viral-factor IX gene transfer approach, adoptive transfer studies provided evidence for activation of regulatory $\mathrm{CD}^{+} \mathrm{T}$ cells capable of suppressing antibody formation to human factor IX. ${ }^{15}$ No suppression was observed when CD4- cells were transferred. Experiments in knockout mice showed that tolerance induction was not dependent on $\gamma \delta$-T cells or $\mathrm{CD}^{+} \mathrm{T}$ cells, which may be involved in regulation during oral tolerance induction. ${ }^{36,37}$ Further analysis of $\mathrm{CD}^{+}{ }^{+}$Treg is under active investigation. Other experiments suggested a requirement for Fas-Fas ligand mediated apoptotic cell death for maintenance of antigen-specific tolerance. 15

\section{Direct Evidence for $\mathrm{CD}^{+} \mathrm{T}$ Cell Tolerance in Transgenic Mice}

A precise immunological characterization of tolerance induction in the factor IX gene transfer system faces several limitations. Antigen-specific T cells are rare and cannot be specifically identified. These limitations can be overcome by use of a mouse that is transgenic for a specific $\mathrm{T}$ cell receptor. The model we chose is based on BALB/c mice that express the chicken ovalbumin (ova)-specific T cell receptor on $80 \%-90 \%$ of their $\mathrm{CD}^{+}$thymocytes. ${ }^{38}$ This $\mathrm{T}$ cell receptor is specific for the ova peptide 232-339 and is encoded by the rearranged $\mathrm{V} \alpha 13$ and V $\beta 8.2$ genes. The ova peptide is presented to the T cell receptor by the $\mathrm{MHC}$ class II molecule $\mathrm{I}_{-} \mathrm{A}^{\mathrm{d}}$. The high number of ova specific $\mathrm{CD}^{+}{ }^{+} \mathrm{T}$ cells allows for extensive in vitro and in vivo studies not possible in non-transgenic mice. Lymphocytes isolated from lymphoid organs from naïve DO11.10 mice are responsive to in vitro cell culture containing ova protein or peptide. Physically tracking these cells is made possible by staining with clonotypic KJ1-26 monoclonal antibody specific to the D011.10 $\mathrm{T}$ cell receptor followed by flow cytometry. This experimental approach has been successfully used to uncover mechanisms of oral tolerance induction. ${ }^{39,40}$

Hepatic administration of an adeno-associated viral vector resulted in vector dose-dependent systemic expression of ova similar to experiments with factor IX. ${ }^{41}$ Lymphocytes from the spleen, thymus, inguinal and portal lymph nodes were harvested and examined at various time points after gene transfer. Re-stimulation of lymphocyte cultures with ova showed a reduction in IL-2 cytokine release compared to control mice (transduced with adeno-associated viral-green fluorescent protein vector) as early as 10 days after gene transfer. Lack of cytokine production correlated with lack of lymphocyte proliferation, which was largely reversed by addition of exogenous IL-2 indicating $\mathrm{T}$ cell anergy. ${ }^{41}$ Numbers of ova-specific $\mathrm{CD}^{+} \mathrm{T}$ cells were significantly reduced among thymocytes, splenocytes and lymph node cells by 1-2 months after gene transfer. By 2 months, the proportion of ova-specific cells was reduced among $\mathrm{CD} 4^{+} \mathrm{T}$ cells. Together, these data suggest clonal deletion and negative selection against ova-specific $\mathrm{CD}^{+} \mathrm{T}$ cells. Both thymic and peripheral deletion/selection mechanisms may play a role in reducing numbers of ova-reactive $\mathrm{T}$ cells. Evidence for $\mathrm{T}$ cell anergy and increased apoptotic cell death of ova-specific $\mathrm{CD}^{+} \mathrm{T}$ cells was also obtained after adoptive transfer of DO11.10 transgenic CD4 ${ }^{+} \mathrm{T}$ cells to non-transgenic BALB/c mice followed by hepatic adeno-associated viral-ova injection. ${ }^{41}$

\section{Are Naturally Occurring Regulatory T Cells Involved?} Recently, attention has increasingly focused on the role of naturally occurring $\mathrm{CD} 4{ }^{+} \mathrm{CD} 25^{+}$Treg. ${ }^{35}$ This subpopulation consists of approximately $10 \%$ of the total $\mathrm{CD}^{+} \mathrm{T}$ cells, is required to prevent autoimmunity and can efficiently suppress activation of $\mathrm{CD}^{+}{ }^{+} \mathrm{CD} 25^{-} \mathrm{T}$ cells.$^{35,42}$ Activation of the $\mathrm{CD}^{+} \mathrm{CD} 25^{+}$Treg cells has been reported in oral and intravenous tolerance models. ${ }^{43}$ Treg cells have also been reported to prevent immune-mediated pathology in several disease models, including autoimmune thyroiditis, Helicobacter hepaticus-induced colitis and pulmonary hyper-inflammation. ${ }^{44-46} \mathrm{CD} 4^{+} \mathrm{CD} 25^{+}$Tregs nonspecifically suppress $\mathrm{CD} 4^{+} \mathrm{CD} 25^{-} \mathrm{T}$ cells in vitro, but are thought to act in a more antigen-specific manner in vivo. ${ }^{47}$ Interestingly, by 60 days after adeno-associated viral-ova hepatic gene transfer to DO11.10 transgenic mice, the percent of $\mathrm{CD} 4^{+} \mathrm{CD} 25^{+} \mathrm{T}$ cells increased (compared to control mice) in the thymus, spleen and lymph nodes. ${ }^{41}$ In vitro assays were used to confirm Treg function of these cells. This increased population of $\mathrm{CD} 4{ }^{+} \mathrm{CD} 25^{+}$cells likely contributes to ova-specific $\mathrm{T}$ cell anergy, thereby helping to maintain $\mathrm{T}$ cell tolerance towards the ova transgene product. Using the adoptive $\mathrm{T}$ cell transfer of $\mathrm{CD}^{+}{ }^{+} \mathrm{CD} 25^{+} \mathrm{T}$ cells, Gross et al. reported that these cells prevented an immune response to adeno-associated viral gene transfer to skeletal muscle. ${ }^{48}$ Our laboratory is currently investigating a potential role of regulatory $\mathrm{CD} 4{ }^{+} \mathrm{CD} 25^{+} \mathrm{T}$ cells in prevention of antibody and cellular immune responses to the transgene product in the context of hepatic adeno-associated viral gene transfer.

\section{Potential Hurdles for Clinical Application}

Despite these encouraging results, which document the possibility of using hepatic gene transfer for sustained therapeutic gene transfer and induction of immune tolerance, several aspects of the biology of gene transfer may limit success of this strategy in clinical application. It is at least theoretically possible that observations on tolerance induction in rodent models will not translate to humans. Already, there are differences in the success rate of tolerance induction in different strains of mice, indicating a role of the genetic background. ${ }^{10,15}$ Nonetheless, data from canine models of hemophilia suggest that hypo-responsiveness of the immune system to factor IX antigen after hepatic gene transfer is not limited to mice, but may also be seen in other species. ${ }^{14} \mathrm{We}$ would also like to point out that selection criteria for matching donors and recipients are less stringent in liver transplants compared to other organs in human patients and that hepatic allografts are possible even across incompatible HLA barriers supporting the idea of using liver as a tolerogenic organ of gene transfer. ${ }^{49,50}$ 
A second concern is the impact of the antigen itself. For example, tolerance induction by hepatic gene transfer is possibly more difficult for factor VIII than for the antigens described above. T cell responses to factor VIII in humans are complex, involving a large repertoire of epitopes. ${ }^{51,52}$ The prevalence of inhibitor formation in hemophilia $\mathrm{A}$ in conventional protein-based therapy is substantially higher than in hemophilia B (20\%-30\% vs. 3\%-4\%) and avoiding antibody responses to factor VIII after hepatic gene transfer in murine and canine models has been more challenging than in factor IX gene transfer. ${ }^{53-55}$

Third, published studies were performed in naïve animals, while human patients (perhaps with the exception of young children) typically have antigen-experienced $\mathrm{T}$ cells to the transgene product (and often to the viral vector as well due to natural infection). For example, in contrast to our experience in hemophilia B mice and dogs, expression of factor IX following adeno-associated viral-mediated hepatic gene transfer in patients with severe hemophilia B was not sustained, despite absence of an antibody response to factor IX. ${ }^{56}$ Ongoing studies are designed to test the hypothesis that reactivation of memory $\mathrm{T}$ cells to adeno-associated viral capsid was responsible for loss of transduced hepatocytes. ${ }^{56}$ The impact of memory $T$ cells on tolerance induction and strategies to block such responses should be explored.

\section{Conclusions}

Experiments described above demonstrate that adeno-associated viral-mediated gene transfer to the liver can induce immune tolerance to the transgene product. Other laboratories have now shown that these observations extend beyond factor IX gene transfer and have implications for treatment of other diseases, such as lysosomal storage disorders. ${ }^{57}$ Antigen levels play a critical role in tolerance induction, which involves a combination of mechanisms, including $\mathrm{T}$ cell anergy, deletion and activation of regulatory $\mathrm{T}$ cells. Additional experiments should enable us to further define subsets of regulatory $\mathrm{CD}^{+} \mathrm{T}$ cells involved. During translation of this approach to clinical application, one has to keep in mind that data in pre-clinical models developed thus far were from animals naïve to vector and transgene products prior to gene transfer, while human subjects may have memory $\mathrm{T}$ cells. Nonetheless, robust tolerance induction in animal models of human disease is encouraging for going forward with in vivo gene therapy protocols.

\section{References}

1. Giannelli F, Green PM. The molecular basis of hemophilia A and B. Baillieres Clin Haematol 1996;9:211-228.

2. Mariani G, Siragusa S, Kroner BL. Immune tolerance induction in hemophilia A: a review. Semin Thromb Hemost 2003;29:69-76.

3. High KA. Clinical gene transfer studies for hemophilia B. Semin Thromb Hemost 2004;30:257-267.

4. Chuah MK, Collen D, VandenDriessche T. Clinical gene transfer studies for hemophilia A. Semin Thromb Hemost 2004;30:249-256.
5. Manno CS, Chew AJ, Hutchison S, Larson PJ, Herzog RW, Arruda VR, Tai SJ, Ragni MV, Thompson A, Ozelo M, Couto LB, Leonard DG, Johnson FA, McClelland A, Scallan C, Skarsgard E, Flake AW, Kay MA, High KA, Glader B. AAV-mediated factor IX gene transfer to skeletal muscle in patients with severe hemophilia B. Blood 2003;101:2963-2972.

6. Herzog RW, Dobrzynski E. Immune implications of gene therapy for hemophilia. Semin Thromb Hemost 2004;30:215-226.

7. Brown BD, Lillicrap D. Dangerous liaisons: the role of "danger" signals in the immune response to gene therapy. Blood 2002;100:1133-1140.

8. Fields PA, Kowalczyk DW, Arruda VR, Armstrong E, McCleland ML, Hagstrom JN, Pasi KJ, Ertl HC, Herzog RW, High KA. Role of vector in activation of T cell subsets in immune responses against the secreted transgene product factor IX. Mol Ther 2000;1:225-235.

9. Zhang Y, Chirmule N, Gao GP, Qian R, Croyle M, Joshi B, Tazelaar J, Wilson JM. Acute cytokine response to systemic adenoviral vectors in mice is mediated by dendritic cells and macrophages. Mol Ther 2001;3:697-707.

10. Follenzi A, Battaglia M, Lombardo A, Annoni A, Roncarolo MG, Naldini L. Targeting lentiviral vector expression to hepatocytes limits transgene-specific immune response and establishes long-term expression of human antihemophilic factor IX in mice. Blood 2004;103:3700-3709.

11. Jooss K, Yang Y, Fisher KJ, Wilson JM. Transduction of dendritic cells by DNA viral vectors directs the immune response to transgene products in muscle fibers. J Virol 1998;72:4212-4223.

12. De Geest BR, Van Linthout SA, Collen D. Humoral immune response in mice against a circulating antigen induced by adenoviral transfer is strictly dependent on expression in antigen-presenting cells. Blood 2003;101:2551-2556.

13. Nathwani AC, Davidoff A, Hanawa H, Zhou JF, Vanin EF, Nienhuis AW. Factors influencing in vivo transduction by recombinant adeno-associated viral vectors expressing the human factor IX cDNA. Blood 2001;97:1258-1265.

14. Mount JD, Herzog RW, Tillson DM, Goodman SA, Robinson $\mathrm{N}$, McCleland ML, Bellinger D, Nichols TC, Arruda VR, Lothrop CD Jr, High KA. Sustained phenotypic correction of hemophilia B dogs with a factor IX null mutation by liver-directed gene therapy. Blood 2002;99:2670-2676.

15. Mingozzi F, Liu YL, Dobrzynski E, Kaufhold A, Liu JH, Wang Y, Arruda VR, High KA, Herzog RW. Induction of immune tolerance to coagulation factor IX antigen by in vivo hepatic gene transfer. J Clin Invest 2003;111:1347-1356.

16. Chuah MK, Schiedner G, Thorrez L, Brown B, Johnston M, Gillijns V, Hertel S, Van Rooijen N, Lillicrap D, Collen D, VandenDriessche T, Kochanek S. Therapeutic factor VIII levels and negligible toxicity in mouse and dog models of hemophilia A following gene therapy with high-capacity adenoviral vectors. Blood 2003;101:1734-1743.

17. Schiedner G, Hertel S, Johnston M, Dries V, van Rooijen N, Kochanek S. Selective depletion or blockade of Kupffer cells leads to enhanced and prolonged hepatic transgene expression using high-capacity adenoviral vectors. Mol Ther 2003;7:35-43.

18. Xu L, Nichols TC, Sarkar R, McCorquodale S, Bellinger DA, Ponder KP. Absence of a desmopressin response after therapeutic expression of factor VIII in hemophilia A dogs with liver-directed neonatal gene therapy. Proc Natl Acad Sci U S A 2005; 102:6080-6085.

19. Xu L, Gao C, Sands MS, Cai SR, Nichols TC, Bellinger DA, Raymer RA, McCorquodale S, Ponder KP. Neonatal or hepatocyte growth factor-potentiated adult gene therapy with a retroviral vector results in therapeutic levels of canine factor IX for hemophilia B. Blood 2003;101:3924-3932. 
20. VandenDriessche T, Vanslembrouck V, Goovaerts I, Zwinnen H, Vanderhaeghen ML, Collen D, Chuah MK. Long-term expression of human coagulation factor VIII and correction of hemophilia A after in vivo retroviral gene transfer in factor VIII-deficient mice. Proc Natl Acad Sci U S A 1999;96:10379-10384.

21. Zhang J, Xu L, Haskins ME, Parker Ponder K. Neonatal gene transfer with a retroviral vector results in tolerance to human factor IX in mice and dogs. Blood 2004;103:143-151.

22. Flotte TR. Gene therapy progress and prospects: recombinant adeno-associated virus (rAAV) vectors. Gene Ther 2004;11:805-810.

23. Herzog RW, Hagstrom JN, Kung SH, Tai SJ, Wilson JM, Fisher KJ, High KA. Stable gene transfer and expression of human blood coagulation factor IX after intramuscular injection of recombinant adeno-associated virus. Proc Natl Acad Sci U S A 1997;94:5804-5809.

24. Herzog RW, Yang EY, Couto LB, Hagstrom JN, Elwell D, Fields PA, Burton M, Bellinger DA, Read MS, Brinkhous KM, Podsakoff GM, Nichols TC, Kurtzman GJ, High KA. Long-term correction of canine hemophilia $\mathrm{B}$ by gene transfer of blood coagulation factor IX mediated by adeno-associated viral vector. Nat Med 1999;5:56-63.

25. Fields PA, Arruda VR, Armstrong E, Chu K, Mingozzi F, Hagstrom JN, Herzog RW, High KA. Risk and prevention of anti-factor IX formation in AAV-mediated gene transfer in the context of a large deletion of F9. Mol Ther 2001;4:201-210.

26. Wang L, Nichols TC, Read MS, Bellinger DA, Verma IM. Sustained expression of therapeutic level of factor IX in hemophilia B dogs by AAV-mediated gene therapy in liver. Mol Ther 2000;1:154-158.

27. Wang L, Takabe K, Bidlingmaier SM, Ill CR, Verma IM. Sustained correction of bleeding disorder in hemophilia B mice by gene therapy. Proc Natl Acad Sci U S A 1999;96:3906-3910.

28. Snyder RO, Miao C, Meuse L, Tubb J, Donahue BA, Lin HF, Stafford DW, Patel S, Thompson AR, Nichols T, Read MS, Bellinger DA, Brinkhous KM, Kay MA. Correction of hemophilia B in canine and murine models using recombinant adeno-associated viral vectors. Nat Med 1999;5:64-70.

29. Snyder RO, Miao CH, Patijn GA, Spratt SK, Danos O, Nagy D, Gown AM, Winther B, Meuse L, Cohen LK, Thompson AR, Kay MA. Persistent and therapeutic concentrations of human factor IX in mice after hepatic gene transfer of recombinant AAV vectors. Nat Genet 1997;16:270-276.

30. Herzog RW, Mount JD, Arruda VR, High KA, Lothrop CD Jr. Muscle-directed gene transfer and transient immune suppression result in sustained partial correction of canine hemophilia B caused by a null mutation. Mol Ther 2001;4:192-200.

31. Kay MA, High K, Glader B, Manno CS, Hutchison S, Dake M, Razavi M, Kaye R, Arruda VR, Herzog R, McClelland A, Rustagi P, Johnson F, Rasko JEJ, Hoots K, Blatt P, Leonard GB, Addya K, Konkle B, Chew A, Couto L. A phase I/II clinical trial for liver directed AAV-mediated gene transfer for severe hemophilia B. Blood 2002;100:115a.

32. Kay MA, Manno CS, Ragni MV, Larson PJ, Couto LB, McClelland A, Glader B, Chew AJ, Tai SJ, Herzog RW, Arruda V, Johnson F, Scallan C, Skarsgard E, Flake AW, High KA. Evidence for gene transfer and expression of factor IX in haemophilia B patients treated with an AAV vector. Nat Genet 2000;24:257-261.

33. Nakai H, Thomas CE, Storm TA, Fuess S, Powell S, Wright JF, Kay MA. A limited number of transducible hepatocytes restricts a wide-range linear vector dose response in recombinant adeno-associated virus-mediated liver transduction. J Virol 2002;76:11343-11349.
34. Wang L, Cao O, Swalm B, Dobrzynski E, Herzog RW. Major role of local immune responses in antibody formation to factor IX in viral gene transfer to skeletal muscle. Gene Ther 2005 May 12; [Epub ahead of print].

35. Sakaguchi S, Sakaguchi N, Shimizu J, Yamazaki S, Sakihama T, Itoh M, Kuniyasu Y, Nomura T, Toda M, Takahashi T. Immunologic tolerance maintained by CD25+ CD4+ regulatory T cells: their common role in controlling autoimmunity, tumor immunity, and transplantation tolerance. Immunol Rev 2001;182:18-32.

36. Ke Y, Pearce K, Lake JP, Ziegler HK, Kapp JA. Gamma delta T lymphocytes regulate the induction and maintenance of oral tolerance. J Immunol 1997; 158:3610-3618.

37. Chen Y, Inobe J, Weiner HL. Induction of oral tolerance to myelin basic protein in CD8-depleted mice: both CD4+ and CD8+ cells mediate active suppression. J Immunol 1995;155:910-916.

38. Murphy KM, Heimberger AB, Loh DY. Induction by antigen of intrathymic apoptosis of CD4+CD8+TCRlo thymocytes in vivo. Science 1990;250:1720-1723.

39. Watanabe T, Yoshida M, Shirai Y, Yamori M, Yagita H, Itoh T, Chiba T, Kita T, Wakatsuki Y. Administration of an antigen at a high dose generates regulatory $\mathrm{CD} 4+\mathrm{T}$ cells expressing CD95 ligand and secreting IL-4 in the liver. J Immunol 2002;168:2188-2199.

40. Chen Y, Inobe J, Marks R, Gonnella P, Kuchroo VK, Weiner HL. Peripheral deletion of antigen-reactive T cells in oral tolerance. Nature 1995;376:177-180.

41. Dobrzynski E, Mingozzi F, Liu YL, Bendo E, Cao O, Wang L, Herzog RW. Induction of antigen-specific CD4+ T-cell anergy and deletion by in vivo viral gene transfer. Blood 2004;104:969-977.

42. Shevach EM, McHugh RS, Piccirillo CA, Thornton AM. Control of T-cell activation by CD4+ CD25+ suppressor T cells. Immunol Rev 2001;182:58-67.

43. Zhang X, Izikson L, Liu L, Weiner HL. Activation of $\mathrm{CD} 25(+) \mathrm{CD} 4(+)$ regulatory $\mathrm{T}$ cells by oral antigen administration. J Immunol 2001;167:4245-4253.

44. Kullberg MC, Jankovic D, Gorelick PL, Caspar P, Letterio JJ, Cheever AW, Sher A. Bacteria-triggered CD4(+) T regulatory cells suppress Helicobacter hepaticus-induced colitis. J Exp Med 2002;196:505-515.

45. Vasu C, Dogan RN, Holterman MJ, Prabhakar BS. Selective induction of dendritic cells using granulocyte macrophagecolony stimulating factor, but not fms-like tyrosine kinase receptor 3-ligand, activates thyroglobulin-specific CD4+/CD25+ T cells and suppresses experimental autoimmune thyroiditis. J Immunol 2003;170:5511-5522.

46. Hori S, Carvalho TL, Demengeot J. CD25+CD4+ regulatory T cells suppress CD4+ T cell-mediated pulmonary hyperinflammation driven by Pneumocystis carinii in immunodeficient mice. Eur J Immunol 2002;32:1282-1291.

47. Nagler-Anderson C, Bhan AK, Podolsky DK, Terhorst C. Control freaks: immune regulatory cells. Nat Immunol 2004;5:119-122.

48. Gross DA, Leboeuf M, Gjata B, Danos O, Davoust J. $\mathrm{CD} 4+\mathrm{CD} 25+$ regulatory $\mathrm{T}$ cells inhibit immune-mediated transgene rejection. Blood 2003;102:4326-4328.

49. Knolle PA, Gerken G. Local control of the immune response in the liver. Immunol Rev 2000;174:21-34.

50. McCaughan GW, Gorrell MD, Bishop GA, Abbott CA, Shackel NA, McGuinness PH, Levy MT, Sharland AF, Bowen DG, Yu D, Slaitini L, Church WB, Napoli J. Molecular pathogenesis of liver disease: an approach to hepatic inflammation, cirrhosis and liver transplant tolerance. Immunol Rev 2000;174:172-191. 
51. Reding MT, Wu H, Krampf M, Okita DK, Diethelm-Okita BM, Christie BA, Key NS, Conti-Fine BM. Sensitization of CD4+ T cells to coagulation factor VIII: response in congenital and acquired hemophilia patients and in healthy subjects. Thromb Haemost 2000;84:643-652.

52. Reding MT, Wu H, Krampf M, Okita DK, Diethelm-Okita BM, Key NS, Conti-Fine BM. CD4+ T cell response to factor VIII in hemophilia A, acquired hemophilia, and healthy subjects. Thromb Haemost 1999;82:509-515.

53. Chao H, Mao L, Bruce AT, Walsh CE. Sustained expression of human factor VIII in mice using a parvovirus-based vector. Blood 2000;95:1594-1599.

54. Chao H, Walsh CE. Induction of tolerance to human factor VIII in mice. Blood 2001;97:3311-3312.

55. Scallan CD, Lillicrap D, Jiang H, Qian X, Patarroyo-White SL, Parker AE, Liu T, Vargas J, Nagy D, Powell SK, Wright JF, Turner PV, Tinlin SJ, Webster SE, McClelland A, Couto LB. Sustained phenotypic correction of canine hemophilia A using an adeno-associated viral vector. Blood 2003; 102:2031-2037.

56. High K, Tigges M, Manno C, Sabatino D, Arruda V, Herzog R, Rustagi P, Rasko J, Sommer J, Jaworski K, Ragni M, Glader B, Lessard R, Luk A, Couto L, Jiang H, Pierce G, Kay M. Human immune response to AAV-2 capsid may limit duration of expression in liver-directed gene transfer in humans with hemophilia B. Blood 2004;104:121a

57. Ziegler RJ, Lonning SM, Armentano D, Li C, Souza DW, Cherry M, Ford C, Barbon CM, Desnick RJ, Gao G, Wilson JM, Peluso R, Godwin S, Carter BJ, Gregory RJ, Wadsworth $\mathrm{SC}$, Cheng SH. AAV2 vector harboring a liver-restricted promoter facilitates sustained expression of therapeutic levels of alpha-galactosidase A and the induction of immune tolerance in Fabry mice. Mol Ther 2004;9:231-240.

\section{Author Affiliations}

Eric Dobrzynski, PhD

Department of Pediatrics

University of Pennsylvania Medical Center

and The Children's Hospital of Philadelphia

Philadelphia, Pennsylvania

Roland W. Herzog, PhD

Department of Pediatrics

University of Pennsylvania Medical Center

and The Children's Hospital of Philadelphia

Philadelphia, Pennsylvania

Current affiliation:

University of Florida

Gainesville, Florida 